УДК $811.373=162.1$

Г. В. Зимовець

\title{
ПРОБЛЕМА МОТИВОВАНОСТІ ВЛАСНИХ НАЗВ
}

Зимовець Г. В. Проблема мотивованості власних назв.

Статтю присвячено розглядові проблеми мотивованості ергонімів у контексті семантичного статусу пропріативів. Автор виділяє чотири основні типи мотивованості власних назв: описову, метонімічну, метафоричну та символічну. Крім того, простежується зв'язок між типом мотивованості та виконуваною онімом функцією.

Ключові слова: мотивованість, ергонім, метонімія, метафора, символ.

Зимовец Г. В. Проблема мотивированности имен собственных.

Статья посвящена рассмотрению проблемы мотивированности эргонимов в контексте семантического статуса проприативов. Автор выделяет четыре основных типа мотивированности имен собственных: описательный, метонимический, метафорический и символический. Кроме того, устанавливается связь между типом мотивированности и выполняемой онимом функцией.

Ключевые слова: мотивированность, эргоним, метонимия, метафора, символ. 
Zymovets G. V. Problem of motivation in proper names.

The article focuses on the problem of business names motivation in the context of discussion on semantic statues of proper nouns. The author argues for existence of four main motivation schemes of proper names - descriptive, metonymical, metaphorical and symbolical. Moreover, the connection between motivation type and proper name function is established.

Key words: motive, business name, metonymy, metaphor, symbol.

Мотивованість власних назв є предметом наукової дискусії, оскільки не з'ясованою залишається проблема їх семантичного та семасіологічного статусу. Зокрема, О. С. Суперанська вказувала на асемантичний статус онімів 3 огляду на відсутність сигніфікативного компонента значення, оскільки, на думку дослідниці, зв’язок власних назв 3 апелятивами, які їх породили, практично нульовий, а 3 поняттями предметів, які позначає пропріатив, він здійснюється опосередковано через предмет [4, с. 136]. Така позиція може, на перший погляд, видатися зрозумілою та обгрунтованою 3 погляду мовної свідомості пересічного мовця, який стикається 3 власними назвами із незрозумілим для нього зв’язком між семантикою твірної основи та онімом або 3 причин затемнення внутрішньої форми, що має місце у таких старих назвах, як Житомир, Дніпро, або через неясність семантичного зв'язку між апелятивом та похідним від нього пропріативом, що має місце, зокрема, у разі ідеологічних назв вулиць типу вулиия Алішера Навої. Тому формується враження про абсолютно довільний вибір назви для тих або інших референтів. Однак, з іншого боку, факти народної етимології, спрямовані на відтворення псевдовнутрішьної форми, та цікавість до етимології як такої, зокрема до походження власного імені, указують на те, що немотивованість власної назви не є зовсім прийнятним явищем для мовця, через що останній намагається відновити прозорість назви, класифікувати іiі у своїй мовній картині світу.

На теоретичному рівні мотивованість власної назви залишається невирішеною проблемою, для чого існують передумови суто об'єктивного характеру. Одну з причин такого суперечливого ставлення до семантики власних назв убачаємо в дихотомії мовця та слухача. Власні назви, будучи фактами штучної номінації, обов'язково передбачають існування конкретного номінатора, тобто мовця або групи мовців, які надали одиничному референту те або те позначення. 3 позиції такого номінатора всі власні назви є безумовно мотивованими, оскільки даються свідомо, тобто задіяним виявляється певний мотив. Інша річ, що такий мотив може залишатися імпліцитним для іншого учасника комунікації, який володіє відмінними фоновими знаннями, уявленнями, субкодами тощо. Таким чином, уже на момент свого утворення власна назва $є$ суперечливою в аспекті мотивації, оскільки те, що для номінатора є прийнятним мотивом, іншими членами мовної спільноти сприймається як довільний зв’язок між 
доономастичним значенням кореня та семантикою оніма. 3 часом ця суперечність лише поглиблюється, оскільки поступово, внаслідок фонетичних та семантичних змін, зазнає трансформацій план вираження та план змісту лексеми. Ми вважаємо плідним методом для розв'язання проблеми характеру мотивованості власних назв звернутися до розгляду такого відносно нового класу онімів, як ергоніми, тобто власні імена суб'єктів діяльності людини - підприємств, компаній, установ тощо. Суб’єктивний фактор відіграє в цьому класі лексики значно більшу роль порівняно до інших, оскільки існує юридично визначений номінатор власник або власники підприємства, які і надають йому назву, виходячи із своїх уподобань. Як зазначає О. Белей, «добір мотивуючої ознаки (або мотивуючих ознак) визначається не об'єктивною помітністю чи важливістю, а залежить головним чином від суб'єктивної, «авторської» оцінки релевантності певної мотиваційної ознаки» [2, с. 48 ].

У дослідників українського ергономікону зустрічаємо в основному подібне вирішення проблеми мотивованості, а саме розрізнення мотивованих та немотивованих онімів 3 певними відмінностями у використовуваній термінології. Так, Л. Н. Соколова поділяє власні назви на мотивовані та умовно мотивовані. До перших вона відносить ті випадки, коли доономастичне значення співвідноситься 3 відповідним об’єктом (референтом власної назви) за низкою ознак, а саме: місцем розташування, функціональним призначенням, своєрідністю даного об'єкта або його потенційним клієнтом, зовнішньою схожістю об'єкта 3 назвою (наприклад, ресторан «Млин»), та так звані «сухі слова», що прямо називають об'єкт (магазин «Черевички») [3, с. 62]. До умовно мотивованих натомість належать ті ергоніми, доономастичне значення яких не викликає прямих асоціацій 3 названим об'єктом (наприклад, кафе «Алмаз»). Основною функцією таких назв, на думку дослідниці, є не інформативна, а індивідуалізуюча. «Але ці назви не потребують того, щоб їх розуміли та розшифровували. Частіше це так звані фантазійні імена. Люди, що дають такі імена, більше турбуються про те, щоб слово було ефектним, викликало почуття зацікавленості, а не про те, щоб воно було зрозумілим. Такі назви не несуть у собі інформації. Вони лише індивідуалізують» $[3$, с. 68].

О. Белей поділяє фірмоніми, під якими він розуміє назви суб'єктів бізнес-сфери, на такі, які мають прозору мотивацію та неясну мотивацію [2, с. 48]. Фірмоніми зі з'ясованою мотивацією розпадаються на відповідні підгрупи з урахуванням конкретної мотиваційної ознаки, що лежить в основі назви. За кількістю мотивів дослідник виділяе власні назви підприємств однознакові, двознакові та багатознакові. Основними мотиваторами фірмонімів, за даними дослідника, виступають сфера діяльності, продукт виробництва, сировина, організаційна структура та правова форма, а також розташування підприємства. О. Белей визнає 
можливість рекламної мотиваційної ознаки (фірмоніми типу «Шанс», «Кронос», «Фенікс», «Альбіон») [2, с. 56-59] та ідеологічної мотивації $[2$, c. $62-63]$.

С. О. Шестакова зазначає, що існують два основні розряди ЛСІ-ергонімів: мотивовані та рецесивні. До мотивованих вона відносить лексеми, які прямо чи опосередковано вказують на ознаки підприємства, його розміщення, зв'язок з людиною та різними реаліями, тобто дають будь-яку інформацію про об'єкт. Мотивовані у свою чергу членуються на реально мотивовані та умовно мотивовані. Реально мотивовані ергоніми вказують на характер діяльності підприємства та продукцію, місцезнаходження, належність окремій особі чи групі осіб. Умовно мотивовані ЛСІ-ергоніми грунтуються на асоціативних зв’язках, які містять лише натяк на ознаки чи характеристики реалій. Рецесивними дослідниця вважає такі ергоніми, які не містять інформації про предмет номінації і найчастіше являють собою штучні слова, створені шляхом механічного поєднання комбінацій літер [6, с.6-7]. Вони характеризуються не відсутністю мотиву номінації, а його прихованістю.

М. М. Торчинський, розглядаючи проблему мотивованості власних назв, пропонує власну класифікацію, виходячи з основної ознаки денотата, покладеної в основу імені, виділяючи такі мотиватори онімів, як апотропейні, асоціативні, ідеологічні, квалітативні, локативні, меморіальні, номінальні, патронімічні, посесивні, символічні, ситуативні, сутнісні та темпоральні [5, с. 440].

Таким чином, спостерігаємо загалом єдиний підхід у розумінні необхідності розрізнення типів мотиваційних ознак. Розходження більшою мірою стосуються кваліфікування статусу так званих рекламних або ідеологічних мотиваторів. Поза проблемою мотивації залишаються також назви, які позірно не мають мотиву i взагалі не інтерпретуються в морфологічній системі сучасної української мови. Крім того, як вже вказувалося на початку статті, проблема мотивації $є$ тісно пов'язаною 3 вирішенням питання про наявність або відсутність сигніфікативного значення, тобто постає питання, наскільки пов'язаним є доономастичне значення оніма 3 його референтною ситуацією. Для вирішення цієї теоретичної проблеми пропонуємо пов'язати класифікацію мотивацій із тріадою Ч. Пірса і в цьому контексті розрізняємо такі чотири типи мотивації: 1) описова назва, коли головним компонентом ергоніма виступає апелятив на позначення типу підприємства на кшталт «Київський ювелірний завод», інші компоненти таких складених ергонімів вступають в індексальний зв'язок із компонентами фрейму діяльності підприємства; 2) метонімія, яка, на нашу думку, співвідноситься 3 індексальним типом знака, оскільки при метонімічному переносі в основу значення ергоніма покладено ті або ті елементи фрейму виробничої діяльності, тобто має місце просторова суміжність референтів; 3) метафора, яка грунтується на 
порівнянні референтів за певними ознаками, виявляючи їхню подібність, i яка, відповідно, належить до іконічних знаків; 4) символізація, тобто надання назви не за екстенсіональним, а інтенсіональним компонентом. В останньому випадку нова назва грунтується на вже існуючій вторинній моделюючій системі, тобто культурних концептах, мовній картині світу, аксіологічних компонентах. До символічних назв також зараховуємо ергоніми, значення яких формується вже власне в підсистемі ергонімів із типових ергонімних формантів типу Турботекс. Використання того або того типу мотивації, на нашу думку, визначається виконуваними онімами функціями. Зокрема, у разі переважання інформативної складової ергонім утворюється шляхом метонімії або з використанням описового способу. Реалізація персуазивної функції натомість висуває на передній план використання оцінної лексики, механізму алюзій, мовної гри тощо.

Як вже вказували інші дослідники, при утворенні ергоніма може виступати не лише одна мотиваційна ознака, але декілька, що залежить від структурного типу ергоніма, серед яких виділяємо такі: 1) слова, які змінили своє значення внаслідок онімізації або трансонімізації; 2) складні слова; 3) словосполучення; 4) новотвори. Множинність мотиваторів спостерігаємо, насамперед, у другому та третьому структурних типах, хоч онімізовані та трансонімізовані ергоніми також можуть поєднувати індексальну та символічну ознаку. Мотиватори одного ергоніма за своїм характером належать до одного типу або ж поєднують декілька, що спричинене гетерогенністю виконуваних ергонімом функцій. Поєднання в межах одного ергоніма індексального типу мотивації із символічним та ідеологічним, зокрема оцінним або аргументативним, забезпечує виконання назвою одночасно завдань презентації підприємства, повідомлення про характер його діяльності, а також ілокутивного завдання переконати потенційного споживача в перевагах саме цього суб'єкта.

За нашими даними, зібраними $з$ довідника «Жовті сторінки України 2006», основні мотиватори ергонімів мають індексальний характер, відсилаючи до ряду компонентів фрейму виробничої діяльності, зокрема таких, як-от: 1) предмет діяльності («Вина України», «Кераміка», «Абразив», «Контракти-аудит», «Агат», «Ензим», «Коровай», «Норка», «Гібрид-С» (компанія, яка займається вирощуванням насіння, саджанцями), «Ротор» (сільськогосподарська техніка), салон «Багет» (рами для картин), концерн «Надра» (геологія та геологічні дослідження), «Нива»); 2) загальна сфера діяльності («Авіа», «Агро»), 3) адресат діяльності («Ласуня», «Стрілеиь-2000», «Ветеран», клініка лазерної медицини «Естет», «Школярик»); 4) адресант, виражений, як правило, через назву відповідної професії ("Дантист на Подолі», «Наи доктор», «Верстатник», «Котельник», «Монтажник», "Дальнобійник»), 5) місце здійснення діяльності («Друкарський двір», «Квіткова садиба», «Кузня», «Земля», «Акваторія»), 6) організаційна форма діяльності («Укрзернохолдинг», 
«Ксерочентр», «Альянс», «Ліга»). Деякі з наведених ергонімів одночасно поєднують інформативний та символічні компоненти, успадковані від апелятива, який лежить у їх основі (коровай як символ національної культури, оцінні іменники ласуня, естет). Метонімічні номінації $\epsilon$ прозорими 3 точки зору адресата, що виключає можливість їхньої двозначної інтерпретації і створює передумови для успішного виконання ними інформативної функції. Водночас їхня здатність створювати нові символічні смисли наближається до нуля, що зменшує ступінь персуазивного впливу на потенційного адресата, оскільки кількість асоціативних зв'язків таких назв обмежується власне фреймом діяльності. Більший потенціал впливу спостерігаємо в імен, створених шляхом синекдохи від апелятивів, які входять до різних тематичних полів, пов'язаних із діяльністю суб'єкта, перебуваючи на їхній периферії: «Візерунок» (галантерея та біжутерія), «Палітра» (поліграфія), інвестиційний фонд «Заповіт», «Штрих» «Синтез» (хімічна промисловість), «Вексель» (страхування), «Абетка» (поліграфія), Акціонерний поштово-пенсійний банк «Аваль», «Карат» (ваговимірювальне та лабораторне обладнання). Крім того, онімізуються також лексеми на позначення цілей діяльності: «Сяйво» (електротовари та освітлювальні прилади); «4 сторони» (туристичні послуги); «Оселя» (сантехнічне обладнання та аксесуари). Такі назви потенційно виводять назву із обмеженого фрейму певної виробничої діяльності, відкриваючи можливості для нових інтерпретацій, мовної гри, створення асоціацій з іншими лексичними групами.

Ми вважаємо, що індексальні власні назви становлять найпростіший тип семантичних відносин між ергонімом та вихідним апелятивом. Мотивація має складніший характер у разі метафоризації або символізації. Під метафорою розуміємо такі випадки перенесення значення, коли наявне порівняння суб’єкта діяльності з яким-небудь іншим референтом, в основі таких ергонімів лежать певні властивості або характеристики виробу чи компанії («П'ятий океан», «Сахара-плюс», «Криниця»). Назва фермерського господарства «Чисті джерела» порівнює якість продукту із якістю водних джерел. Ергонім юридичної фірми «Джерело» вказує на значення діяльності компанії для отримання інформації. У назві «Mалахіт» (кріплення, болти тощо) спостерігаємо порівняння властивостей продукції з каменем. Ергонім «Оберіг» (кабелі, проводи, дріт) указує на функції продукції. У деяких випадках підставою для переносу значення $\epsilon$ аналогічність виконуваних функцій: «Доктор» (ремонт та обслуговування офісної техніки). Як правило, метафоризація відбувається на рівні не окремого слова, а радше словосполучення: «Дари сонцяя, дитяча громадська організація «Квіти майбутнього», авіаційна компанія «П'ятий океан». Метафори виконують насамперед експресивну та емотивну функцію, що посилює ілокутивний вплив на адресата. Цей механізм, за нашими даними, не є типовим способом утворення ергонімів, 
на відміну від символізації, при використанні якої ергонім відсилає швидше до конотацій апелятива, культурно обумовлених смислів, етнічних концептів тощо. Фактично в цьому разі значення базуються вже на вторинній моделюючій системі, означником якої виступає не лише мова, але й створена за іiі посередництвом культура. Таким чином, у разі ергонімів маємо справу вже 3 третинною моделюючою системою, означником якої виступають з одного боку, зв'язки в межах самої мовної системи, а з іншого боку, - поняття, уявлення, концепти, експліцитно представлені в культурі. Символічна мотивація $є$ відмінною за своїм характером, оскільки інтенсіонал мовного знака відсилає до різних вторинних символічних систем, у чому й полягає складність визначення семантичного зв'язку між апелятивом та онімом 3 огляду на розпливчастість утворених конотацій. «Що стосується конотативного означуваного, то воно має всеохоплюючий, глобальний, розпливчастий характер: це - фрагмент ідеології» [1, с. 150]. Найпоширенішими серед ергонімів підтипами символічної мотивації $є$ такі: 1) ідеологія, 2) естетика, 3) аксіологічний компонент (суб'єктивна оцінка), 4) прецеденті назви, 5) меморіальні назви. Така розмитість спричиняє складність аналізу символічних назв, оскільки для їх витлумачення виходимо за межі власне лінгвістики в культурологію та прагматику.

До типових тематичних груп апелятивів, від яких утворюються символічні власні назви, належать: назви рослин («Едельвейс Плюс», «Крокуси», «Арніка»), назви тварин («Білий ведмідь», «Чорний беркут», «Oca»), назви каменів («Агат», «Кристал Лайн», «Сапрip Траст»), космічні терміни («Орбіта-сервіс», «Сатурн-Україна», «Астероїд»), назви літер грецького алфавіту («Омега-авто», «Альфа-метал», «Дельта-А»), терміни мистецтва («Акорд», «Камертон», «Вернісаж»), морські терміни («Галеон», «Компас», «Лагуна»), військові терміни («Легіон», «Салют», «Центруіон»), хімічні терміни («Октан», «Радон») тощо. Символізація має місце не лише в процесі онімізації апелятивів. Символічні ергоніми також утворюються шляхом трансонімізації від прецедентних назв («Земля $i$ воля», «Золоте руно», "П'ятий елемент»), міфонімів («Кронос-лтд», «Меркурій-иентр», «Одісея-тур»), топонімів («Атлантик», «Коринф»). Безумовно, що використання таких ергонімів 3 умовно-символічною мотивацією має як свої плюси, так і мінуси. Їхнім сильним боком $\epsilon$ значний потенціал впливу на адресата завдяки використанню значної кількості асоціацій. Проте, з іншого боку, переважання конотацій у мотивуванні ергоніма ставить обмеження для глобального поширення назви 3 огляду на міжкультурні відмінності щодо характеру та обсягу конотацій, наявності / відсутності тих або тих концептів у різних культурах, що мінімізує персуазивний вплив подібних ергонімів.

Частою стратегією утворення ергонімів виступає використання суто конотативних значень, зокрема аксіологічної лексики, що ми відносимо до 
символічного типу мотивації. У цьому випадку як означник виступає зафіксована в мові система оцінок i позитивних конотацій, тобто мотиватором $\epsilon$ не денотативний компонент значення апелятива, а його конотації: «Надійний компаньйон», «Нова ера», «Професійні системи», «Смачний хліб». Це можуть бути слова на позначення позитивної оцінки («Шарм»); успішності роботи суб’єкта («Глорія»); указівка на розміри або позицію суб’єкта («Гранд», «Авангард»); належність до престижної соціальної групи («Еліт Трейд»); оцінка щодо відповідності стандартам («Iдеал»; «Класик»; «Абсолют»). Звичайно, ця стратегія номінації характерна для підприємств тих сфер діяльності, забезпечення результатів у яких безпосередньо залежить від успішності досягнення цілей у комунікації з клієнтом, тобто у виробництві тієї продукції та послуг, споживачами яких виступають звичайні люди, а не підприємства.

Певну проблему в аспекті витлумачення мотивованості становлять ергоніми - нові слова, які на перший погляд перебувають поза межами мовної системи, на кшталт «Новекс», «Ерготек», «Юрек». Такі випадки, зокрема, розглядаються як ергоніми, що містять так звані фіналі та ініціалі. Ці власні назви побудовані аналогічно до відповідних абревіатурних ергонімів («Южтранссервис», «Чорномортехфлот»), утворених від атрибутивних словосполучень. Їхнє семіотичне витлумачення, на наш погляд, також можна провести, спираючись на сформульоване $\Phi$. де Соссюром поняття значущості. Такі новотвори легко піддаються об’єднанню в один клас на підставі наявності в їхньому складі елементів, що повторюються. Тому саме типові фіналі й ініціалі (ергономічні компоненти) сигналізують про те, що ця лексема входить до ергономікону. Присутність подібних компонентів допомагає ідентифікувати лексему як комерційну назву, полегшуючи розуміння змісту повідомлення адресантом. У цьому випадку означником ергоніма виступає морфологічна система мови.

Отже, створення нового смислу в різних ергонімах варіює від простого метонімічного переносу до складних семантичних зв'язків, опосередкованих не лише системою мови, але і всією культурою, яка стоїть за нею. Тому семантичне дослідження будь-яких власних назв потребує виходу в зовнішню лінгвістику для залучення даних інших наук гуманітарного циклу.

\section{Література}

1. Барт Р. Основы семиологии / Р. Барт // Структурализм: «за» и «против» : [сб. науч. статей]. - М. : Прогресс, 1975. - С. 114-163.

2. Белей О. О. Сучасна українська ергонімів : власні назви підприємств Закарпаття / О. О. Белей. - Ужгород, 1999. - 111 с.

3. Соколова Л.Н. Типи мотивованості ергонімів (на матеріалі ергонімів м. Києва) / Л. Н. Соколова. - Мовознавство. - 1993. - № 6. - С. 65-69. 
4. Суперанская А. В. Общая теория имени собственного / А. В. Суперанская. М. : Наука, 1973. - 366 с.

5. Торчинський М. М. Структура онімного простору української мови / М. М. Торчинський. - Хмельницький : Авіст, 2008. - 543 с.

6. Шестакова С. О. Лексико-семантичні інновації в системі української номінації (на матеріалі ергонімів і прагмонімів) : автореф. дис. на здобуття наук. ступеня канд. філ. наук : спец. 10.02.01 «Українська мова» / С. О. Шестакова. - Харків, 2002. - 20 с.

Стаття надійшла до редакиії 18.10.2010 p. 